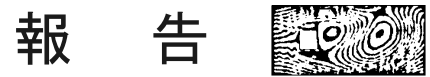

\section{第 8 回日中韓風工学に関する国際ワークショップ参加報告 \\ Report of the 8th China-Japan-Korea International Workshop on Wind Engineering (CJK2013)}

八木知已 *

Tomomi YAGI

表記ワークショップが 2013 年 5 月 11 日から 12 日にかけて, 中国河北省石家庄市の石家庄鉄道大学 (Shijiazhuang Tiedao University) で開催された。本 会議は, 2005 年より日本風工学会 (JAWE) と韓国 風工学会（WEIK）が持ち回りで開催してきた日韓 風工学会議 (JaWEiK) が, 昨年度, 韓国の浦項工科 大学 $(\mathrm{POSTECH})$ で開催された第 7 回会議より, 正 式に中国の風工学研究者も参加し, 日中韓風工学会 議（CJK）として生まれ変わったものである。

今回のワークショップは, 石家庄鉄道大学, 同済 大学の State Key Laboratory of Disaster Reduction in Civil Engineering, Wind Engineering Group of China が 主催し, 石家庄鉄道大学の Qingkuan Liu 教授が中心 となってお世話して頂いた。鳥インフルエンザウイ
ルス「H 7 N 9 型」の発生もあり, 日本と韓国から の参加者は少な目ではあったが，無事何の問題もな く開催された。会議参加者は, 中国から 41 人, 韓国 から 6 人, 日本風工学会からの参加者は, 山田均会 長, 植松康理事, 勝地弘理事, 田村幸雄理事, 筆者 の 5 名であった (写真 1 参照)。

開会式では, 石家庄鉄道大学の Qingkuan Liu 教授 の挨拶に続き, 同済大学の Yaojun Ge 教授, 山田均 日本風工学会会長 (写真 2 参照), 韓国風工学会会長 の Sang Joon Lee 教授, 世界風工学会会長の田村幸雄 理事がそれぞれスピーチを行った。また, 会議初日 の午前中には, 石家庄鉄道大学の教授陣 25 名と大学 院生 115 名も参加し, 200 名近い聴衆が会場を埋め ていた (写真 3 参照)。

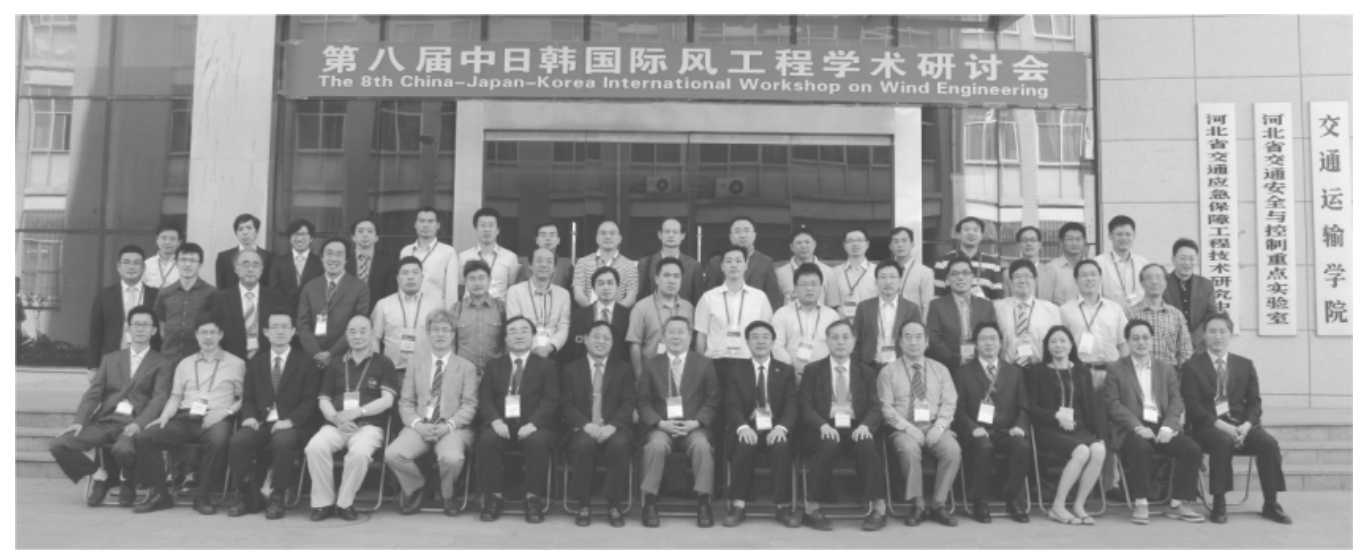

写真 1 ワークショップ参加者集合写真

* 京都大学大学院工学研究科社会基盤工学専攻 准教授

Associate Professor, Department of Civil and Earth Resources Engineering, Kyoto University 


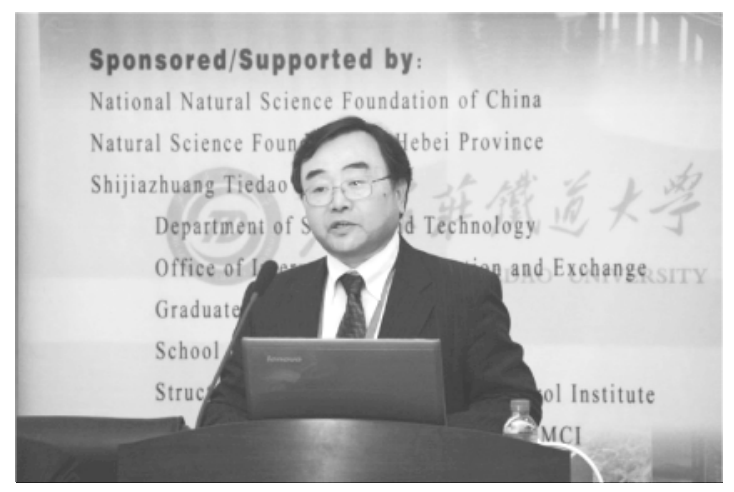

写真 2 開会式で挨拶する山田会長

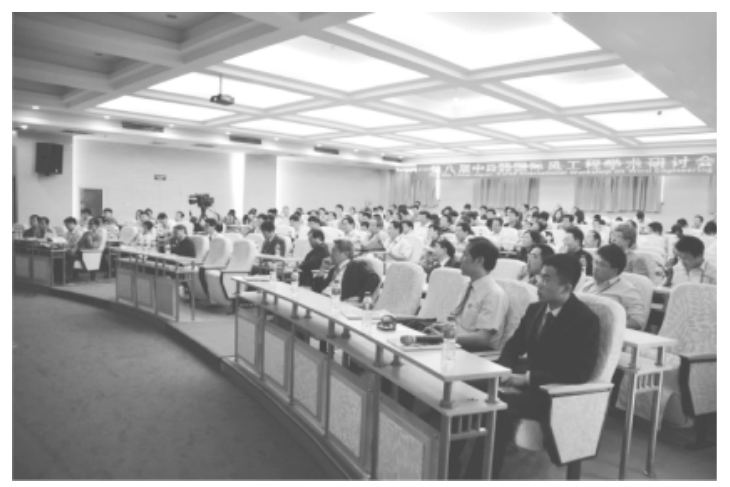

写真 3 会場風景

発表は 2 日間で 4 セッション行われ，以下の 22 件の発表が行われた。

\section{Session A: Structure}

1) Combination and correlation of wind force components, Yukio Tamura (Tokyo Polytechnic University)

2) Comparison of equivalent static wind loads of several wind load codes for circular high-rise structures in across-wind direction, Shuguo Liang (Wuhan University)

3) Wind force coefficients for designing H.P.-shaped canopy roofs, Yasushi Uematsu (Tohoku University)

4) The atmospheric boundary layer and wind loads on tall buildings in mountain areas, Zhengliang $\mathrm{Li}$ (Chongqing University)

5) Evaluation of measured damping ratio of tall RC buildings in Korea, Hongjin Kim (Kyungpook National University)

6) Corner modification effects on aerodynamic forces of high-rise buildings, Yalin Yan (China Academy of
Building Research)

\section{Session B: Bridge}

7) Development and challenges in three main approaches of wind engineering, Yaojun Ge (Tongji University)

8) Vortex-induced vibration and its countermeasures of a long-span cable-stayed bridge, Hiroshi Katsuchi (Yokohama National University)

9) Study on flutter stability of narrow suspension bridge, Hua Bai (Changan University)

10) Time-domain aeroelastic analysis of bridge using a truncated Fourier series of the aerodynamic transfer function, Jinwook Park (Seoul National University)

11) Some aspects of vortex-induced vibration and flutter of long-span bridges, Mingshui Li (Southwest Jiaotong University)

12) Reliability-based wind load factor for the design of long-span bridges, Chul Hwan Yoo (Seoul National University)

\section{Session C: Structure}

13) Wind engineering studies for improving ventilation flows in huge factory building, Sang Joon Lee (Pohang University of Science and Technology)

14) Wind pressure on roof claddings, Qingshan Yang (Beijing Jiaotong University)

15) Microburst effects on roof structure, Yong Chen (Zhejiang University)

16) Vibration control of aeroelastic motion using active mass damper, Jae Seung Hwang (Chonnam National University)

17) Calculation methods of wind-induced internal pressures for a two-compartment building, Xianfeng $\mathrm{Yu}$ (South China University of Technology)

18) Effect of turbulence integral scale on buffeting response of a transmission line tower, Xugang Hua (Hunan University)

\section{Session D: Other topics}

19) Numerical simulation of wind profiles over moving waves with different wave age, Shuyang Cao (Tongji University)

20) Interferences of vortex sheddings in galloping instability of rectangular cylinders, Tomomi Yagi (Kyoto University)

21) Effects of aspect ratio and wind direction on flow characteristics around rectangular obstacles, Hee 


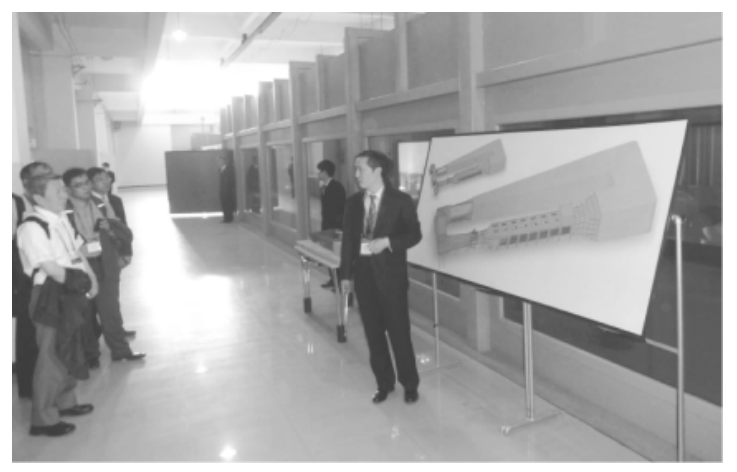

写真 4 風洞を案内する Liu 教授

Chang LIM (Pusan National University)

22) Codes comparison and wind tunnel simulation of wind induced snowdrift, Qingkuan Liu (Shijiazhuang Tiedao University)

また, 初日の夕方には, Qingkuan Liu 教授の案内 で石家庄鉄道大学の Wind Engineering Research

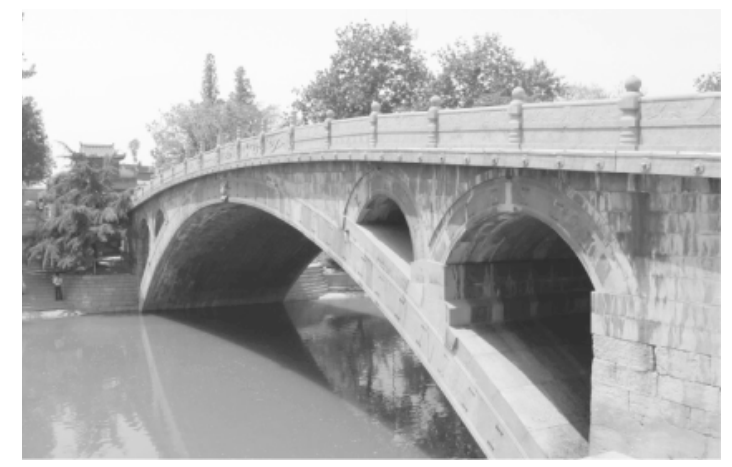

写真 5 趙州橋

Center の風洞見学が行われた (写真 4 参照).さらに, 2 日目のセッション終了後には, 約 1400 年前の隋の 時代に建設された趙州橋（Zhaozhou Bridge）へのテ クニカルツアーも行われた（写真 5 参照）。

閉会式では，次年度の開催国である日本側より, 山田会長に代わり植松理事が挨拶を行った。次回の 開催場所と時期については，未定とのことである。 